\title{
The effect of pressure depression on the water inflow volume to wells which cover carbonate rocks in the Carpathian Foredeep basement, SE Poland
}

Rudarsko-geološko-naftni zbornik

(The Mining-Geology-Petroleum Engineering Bulletin) UDC: $553.9,622.2$

DOI: 10.17794/rgn.2021.2.4

Preliminary communication

\author{
Mirosław Rzyczniak; Marek L. Solecki; Dagmara Zeljaś; Stanisław J. Dubiel \\ AGH University of Science and Technology, Faculty of Drilling, Oil \& Gas, Mickiewicza 30, 30-059 Kraków, Poland
}

\begin{abstract}
This paper presents an analysis of well testing data, performed with a Drill stem test (DST). The carbonate levels of Mesozoic reservoir rocks were investigated in the research area of the Carpathian Foredeep. Based on the results of 17 two-cycle DST reservoir tests, the dependence of the volume of the reservoir water flow rate from the Mesozoic carbonate reservoirs (Upper Jurassic, Lower Cretaceous) to the wells as a function of the mean depression of bottom pressure was researched in the selected oil exploration area in the Carpathian Foredeep basement, SE Poland. Using methods of statistical analysis, a satisfactory correlation between variables for power and the exponential model was found, and a weak correlation for the linear model was found. A decrease in the value of the reservoir water flow rate along with an increase in pressure depression was found for the Mesozoic carbonate reservoirs, which may indicate the occurrence of fractures and micro-fractures shortening under extreme pressure depression and blockage phenomena of fractures and cavernous pores in the perimeter area by solid particles (cuttings, salt, polymers, etc.).
\end{abstract}

\section{Keywords:}

Carpathian Foredeep; Mesozoic; DST test; statistics, water flow volume.

\section{Introduction}

Since the Second World War, intensive geological and exploration works were carried out for oil and gas reservoirs in the Polish part of the Carpathian Foredeep and its basement (i.e. Cisek and Czernicki, 1965; Karnkowski, 1994; Karnkowski and Ozimkowski, 1998; Borys et al., 2000; Myśliwiec et al., 2006); in the 1990s especially in the area between Rzeszów and Bochnia (see Figure 1) (i.e. Czernicki and Moryc, 1990; Heflik, 1992; Kotarba et al., 1998).

This research was carried out, inter alia, in Mesozoic carbonate reservoir rocks (upper Jurassic, Lower Cretaceous) separated by well logging, in the profiles of wells (Maksym et al., 2000; Gutowski et al., 2007; Krajewski et al. 2011). Testing the field is one of the most important stages of work in the process of exploring crude oil and natural gas. The results of the trial depend on the further development of the exploration work. One of the methods of testing the drilled levels of reservoir rocks is to use samplers placed into the hole. The use of DST technology allows for quick determination of the value concerning the productivity of the tested level of reservoir rocks. Data from the tests are the basis for the correction of drilling technology, and also help to avoid the unnecessary positioning of a casing column into an un-

Corresponding author: Marek L. Solecki

marek.solecki@agh.edu.pl productive hole. Tests of reservoir rocks with the use of tubular samplers include: placing the sampler into a well at the appropriate depth, isolating the tested productive level from the pressure of the mud column and connecting it to the inner space of the mud pipes in order to induce a flow, obtaining a pressure increase curve, and collecting reservoir samples.

On the basis of the results obtained from the samples, it is possible to determine the formation pressure, well performance, hydrodynamic coefficient, rock permeability, rock permeability damage index of the near-well zone, and the range radius of the production level examination from the well. Prospective horizons were subjected to reservoir tests with tubular reservoir samplers (DST) to assess their productivity. DST tests were most often performed in open-hole sections, and less-hole sections, after previous perforation of the well. US standard Halliburton type and Baker type Inflatable samplers were used. The samplers used for the tests were two-cycle samplers. During the DST reservoir tests of the Mesozoic reservoirs, in about $90 \%$ of cases, twocycle technology was used, i.e. two tests of inflow of reservoir water to the sampler and two tests of bottompressure build-up (Dubiel et al., 1998).

The standard Halliburton type is used for testing the prospective layers of reservoir rocks made available by perforations for a hydrodynamic assessment, as well as for technical tests, e.g., for testing the tightness of a ce- 


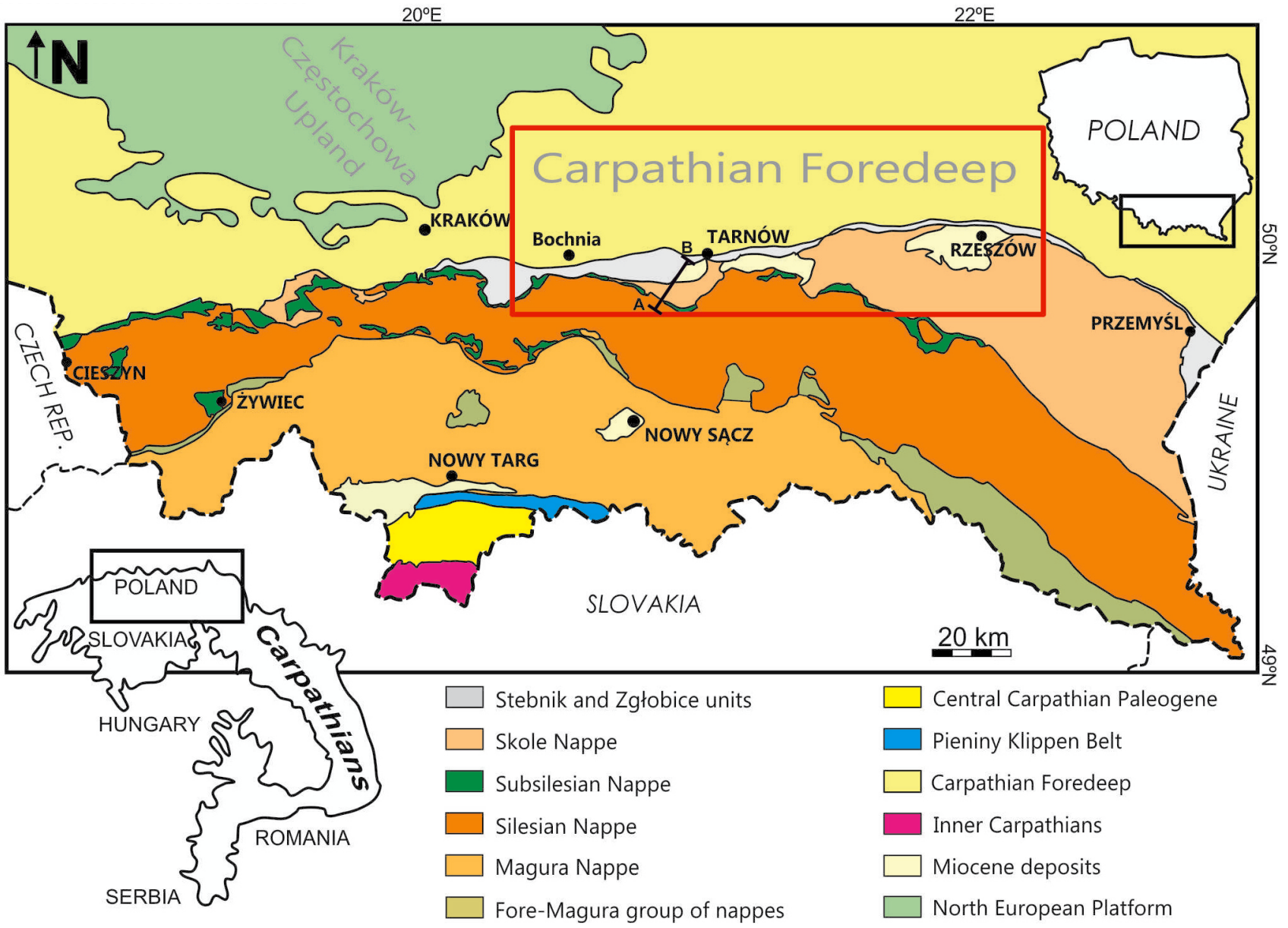

Figure 1. Position of the research area against the tectonic map of the Polish Carpathians and their foreland (map after Żytko et al., 1989; Cieszkowski et al., 20o9; Kowal-Kasprzyk et al., 2o2o; modified)

ment plug or casing pipes. It is especially recommended to use such a set in those cases where the distance from the shoe of the casing column to the non-tubular layer is small (several dozen metres), and the wall of the borehole above this layer is vaulted or when XYZ profiling has not been performed.

The inflatable type is intended for the testing of the prospective layers of reservoir rocks in boreholes with a vaulted wall and in poorly compacted rocks, i.e., in geological conditions that do not allow for sealing with mechanical seals fastened under the action of axial pressure. The advantage of these samplers is the good sealing properties of pumped packers. They make it possible to selectively test several of perspective layers of reservoir rocks in a borehole at once. This method shortens the testing time and minimizes testing costs (Dubiel et al., 1998).

Based on the analysis of well testing data, it was concluded that the inflow of reservoir water during DST tests in exploratory wells after oil and gas reservoirs constitutes a significant percentage of sampling cases of prospective levels determined by well-logging. The interpretation results of data from such tests are now used to design further works in the field of oil exploration as well as to use water-bearing horizons in geothermal energy and to obtain salts (e.g. bromine or iodine).

\section{Geological setting of research area}

The Carpathian Foredeep is part of the large sedimentary basin (the Paratethys Basin) formed in the foreland of the Carpathian Mountains, which slopes to the north. It is a typical pre-mountain trench filled with syn- and postorogenic sediments, the formation of which was related to the Miocene evolution of the orogenic arc of the Outer Carpathians (Krzywiec, 2006). In the west, the Foredeep connects with the Alpine Molasse Basin, and in the east with the pre-mountain basin of the Balkans. It is the youngest alpine unit occurring in Poland, where it extends for a length of about $300 \mathrm{~km}$ and a width of up to $100 \mathrm{~km}$. The basin is filled with Lower and Middle Miocene molasse deposits up to $3 \mathrm{~km}$ thick in Poland and up to $5 \mathrm{~km}$ in the Ukraine (Kovac et al., 1998; Oszczypko, 2006). In terms of lithology, petrography and especially facies, the Miocene reservoir rocks are very diverse. The basement of the Carpathian Foredeep is composed of rocks of the Epivarisian platform and its Permian-Mesozoic cover. The depth of the platform sub- 


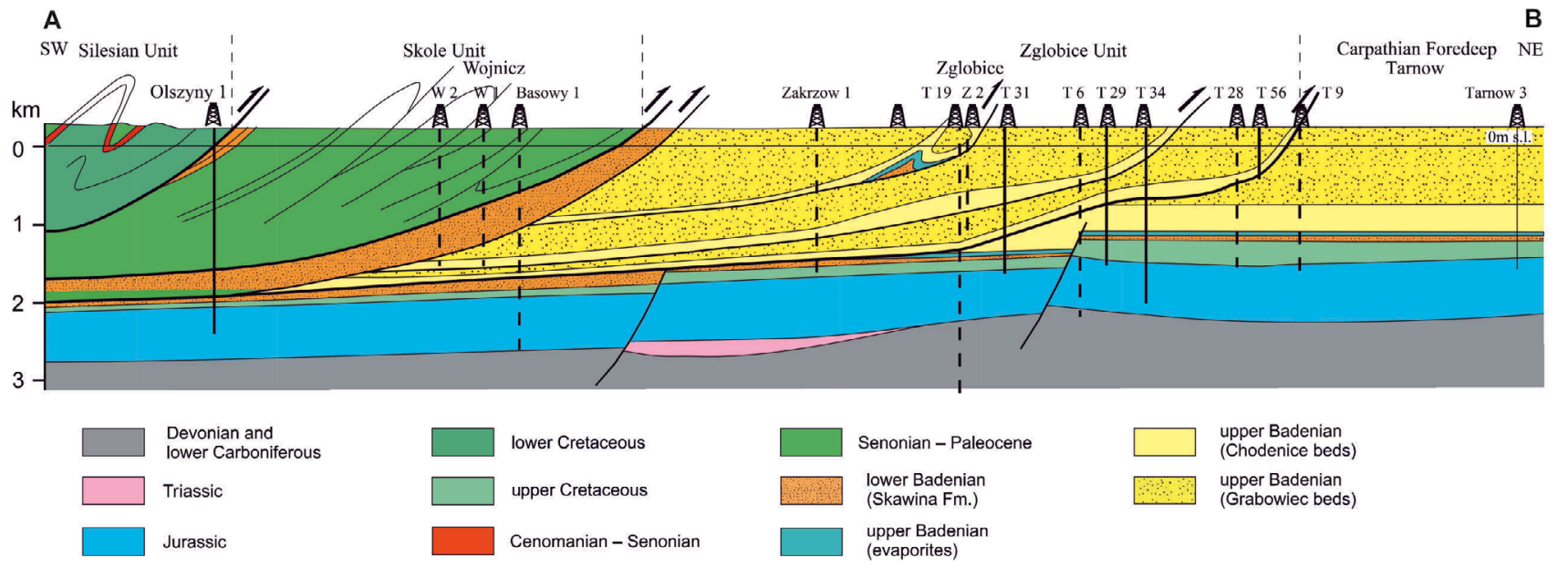

Figure 2. Geological cross-section AB (shown in Figure 1) through the marginal part of the Polish Carpathians and Carpathian Foredeep west of Tarnów (after Oszczypko, 1998; Oszczypko et al., 20o6)

strate in the Foredeep ranges from several hundred metres to $3500 \mathrm{~m}$ (Oszczypko et al., 2006). In the west, under the Miocene of the Carpathian Foredeep, there are rocks of the Upper Silesian Trough, in the central part rocks of the Miechów Trough, and in the east - of the lower San Basin (Stupnicka and Stempień-Sałek, 2016). The northern boundary of the Foredeep is erosive, while the southern boundary is tectonic (Mizerski, 2020). It is delineated by the front of the Outer Carpathians, which are completely flat over the Miocene sediments of the Carpathian Foredeep (Oszczypko et al., 2006).

In the Carpathian Foredeep, the outer part, located north of the Carpathians, and the inner part hidden under the overhung Carpathians are distinguished (Oszczypko 1998). The outer zone, covering the area of the present Foredeep, is filled with middle Miocene marine sediments (Badenian and Sarmatian). Its width on the territory of Poland ranges from $30-40 \mathrm{~km}$ in the west to 90 $\mathrm{km}$ in the east. The inner part of the Foredeep, located under the Carpathian nappes (Skole and Zgłobice Units), is filled with early Miocene land sediments and midMiocene sediments from the marine environment (see Figure 2) (Oszczypko and Slaczka, 1989; Oszczypko 1998, 2006; Oszczypko et al., 2006; Głuszyński and Aleksandrowski, 2016).

The formation of the Carpathian Basin is associated with the end of flysch sedimentation, the uplift and folding of the Outer Carpathians, which was the result of the collision between the European plate and the terranes of Alcapa and Tisza-Dacia with the end of the Burdigalian (Tomek and Hall, 1993).

The Paleozoic-Mesozoic and Neogene strata of the Carpathian Foredeep are oil and gas productive (Karnkowski, 1999; Myśliwiec, 2004; Oszczypko et al., 2006; Szuflicki et al., 2020). The Upper Jurassic series is widespread across the western part of the Carpathian Foredeep (towards the west from Rzeszów). It includes sediment strata from the Oxfordian to Kimmeridgian.
The Oxfordian deposits start from marls, massive limestones with cherts, and cavernous dolomites. The upper Oxfordian consists of organogenic limestones, which pass upward to oolitic limestones. The organogenic rocks were deposited in different facies as bioherms, reef mounds, table-shaped reefs, patch reefs, and deposits of the reef talus. The effective thickness of the reservoir hydrocarbon resources of the Polish Carpathian Foredeep is $12.7 \mathrm{~m}$, the porosity is about $2 \%$, and the permeability ranges from 0 to $184.55 \cdot 10^{-15} \mathrm{~m}^{2}$ ( 0 to 187 $\mathrm{mD})$. The traps are a structural-stratigraphic type of the uplifted block erosional-tectonic origin. The thick cover of the Miocene deposits seals hydrocarbons. Besides the organogenic limestones, the dolomites are also the primary Upper Jurassic reservoir. The results of the laboratory analysis of core data suggest that the dolomites of the Carpathian Foredeep are formed by alternations of limestone rocks. The dolomites are most commonly late diagenetic and epigenetic (Myśliwiec et al., 2006).

\section{Materials and methods}

Well testing data (Dubiel et al., 1998) were used for analyses and calculations, including reservoir tests of the Mesozoic reservoirs in the water-bearing zones of the studied geological structures of the Carpathian Foredeep.

A measure of the productivity of the tested aquifers is usually the average value of the volume flow of the reservoir water inflow $\left(q_{w s r}\right)$ to the sampler (see Table 1), during a two-cycle DST test. Statistical analyses were made taking into account the results of the DST technology tests made in accordance with individually selected parameters for each test. However, in determining this basic reservoir parameter, pressure depression is not taken into account, as an important parameter of the DST test technology. So in this publication, the unitless production $\left(W W_{j}\right)$ index, taking into account the mean value of pressure depression, was used to assess the pro- 
Table 1. Summary of data and results of calculations of the average value of pressure depression and unit extraction index of reservoir water from the Mesozoic strata during DST tests

\begin{tabular}{|c|c|c|c|c|c|c|c|c|c|}
\hline No. & $\begin{array}{l}\text { No. of well; } \\
\text { No. of DST }\end{array}$ & Stratigraphy & $\begin{array}{l}\text { Interval } \\
\text { from - to, (m) }\end{array}$ & $\begin{array}{l}q_{w s i r} \\
\left(\frac{m^{3}}{h}\right)\end{array}$ & $p_{z}(M P a)$ & $p_{p 1}(M P a)$ & $\begin{array}{l}p_{k 2} \\
(M P a)\end{array}$ & $\begin{array}{l}\Delta p_{s r} \\
(M P a)\end{array}$ & $\begin{array}{l}W W_{j} \\
\left(\frac{m^{3}}{h \cdot M P a}\right.\end{array}$ \\
\hline 1 & Z-5; 8/96 & Upper Jurassic - Cretaceous & $1178-1230$ & 4.0 & 11.34 & 2.01 & 3.51 & 8.58 & 0.466 \\
\hline 2 & Z-8; 47/96 & Upper Jurassic & $1280-1299$ & 1.75 & 11.8 & 0.7 & 5.4 & 8.75 & 0.200 \\
\hline 3 & T-1; 77/96 & Upper Jurassic & $2692-2710$ & 1.71 & 27.82 & 5.4 & 27.8 & 11.22 & 0.152 \\
\hline 4 & J-3; 89/96 & Upper Jurassic & 1494-1525 & 1.5 & 15.13 & 5.6 & 6.7 & 8.98 & 0.167 \\
\hline 5 & K-4; 114/96 & Upper Jurassic & $657-702$ & 2.8 & 6.51 & 1.1 & 3.9 & 4.01 & 0.698 \\
\hline 6 & R-3; 118/96 & Jurassic - Cretaceous & $1409-1441$ & 1.275 & 13.47 & 1.6 & 2.5 & 11.42 & 0.112 \\
\hline 7 & $\mathrm{R}-1 ; 3 / 97$ & Jurassic & $2340-2424$ & 0.392 & 23.8 & 2.7 & 21.41 & 11.75 & 0.033 \\
\hline 8 & $Z-7 ; 26 / 97$ & Jurassic & $2980-3015$ & 0.858 & 29.52 & 12.88 & 14.27 & 15.95 & 0.054 \\
\hline 9 & $\dot{\mathrm{Z}}-42 ; 49 / 97$ & Jurassic & $1483-1492$ & 1.08 & 14.67 & 2.21 & 5.16 & 10.99 & 0.098 \\
\hline 10 & W-16; 52/97 & Upper Jurassic & 1868-1904 & 2.0 & 18.52 & 3.96 & 7.36 & 12.86 & 0.156 \\
\hline 11 & Ż-42; 53//97 & Jurassic & $1635-1701$ & 2.5 & 15.283 & 2.46 & 9.77 & 9.17 & 0.273 \\
\hline 12 & W-3; 56/97 & Upper Jurassic - Cretaceous & $1338-1356$ & 3.6 & 12.46 & 3.54 & 11.14 & 5.12 & 0.703 \\
\hline 13 & W-3; 64/97 & Upper Jurassic & 1446-1498 & 21.0 & 13.57 & 8.8 & 13.4 & 2.47 & 8.502 \\
\hline 14 & O-3; 70/97 & Jurassic & $1574-1577$ & 6.6 & 15.29 & 1.36 & 15.07 & 7.08 & 0.933 \\
\hline 15 & P-2; 73/97 & Jurassic & $1708-1728$ & 9.0 & 16.95 & 4.9 & 16.86 & 6.07 & 1.483 \\
\hline 16 & Ł- $20 ; 12 / 98$ & Upper Jurassic & $1503-1542$ & 9.0 & 14.71 & 3.13 & 12.66 & 6.82 & 1.321 \\
\hline 17 & Ł-20; 13/98 & Jurassic & $2155-2173$ & 0.36 & 21.403 & 6.26 & 7.55 & 14.50 & 0.025 \\
\hline
\end{tabular}

ductivity of the examined aquifers (see Table 1) and was calculated from the formula (Dubiel et al., 2003):

$$
W W_{j}=\frac{q_{w s ́}}{\Delta p_{s r}}
$$

where:

$W W_{j}$ - reservoir water unit extraction rate, $\left(\frac{m^{3}}{h \cdot M P a}\right)$,

$q_{w s r}$ - average value of the stream of the reservoir water inflow to the sampler during the twocycle DST reservoir test, $\left(\frac{m^{3}}{h}\right)$,

$\Delta p_{s r}-$ mean value of pressure depression during the first and second cycle of flow test, (MPa).

The average pressure depression for the first and second cycle of inflow test was calculated using the formula:

$$
\Delta p_{s r}=p_{z}-\frac{\left(p_{p 1}-p_{k 2}\right)}{2}
$$

where:

$p_{z}$ - reservoir pressure determined from the extrapolation of the second bottom pressure buildup curve, (MPa);

$p_{p 1}$ - pressure recorded at the beginning point of the first curve of water flow to the probe, $(\mathrm{MPa})$;

$p_{k 2}-$ pressure recorded at the end point of the second curve of water flow to the probe, $(\mathrm{MPa})$.

Data for calculations and results of calculations are presented in Table 1.

\section{Results and discussion}

In assessing the productivity of aquifers, important information on the rational technological conditions of water extraction can be obtained (Dubiel et al., 2003) on the basis of statistical analysis of the results of DST reservoir tests performed in the selected area. For this purpose, the dependence of the flow rate of the reservoir water inflow to the reservoir sampler on pressure depression exerted on the tested aquifer is examined.

Using methods of statistical analysis, based on a scatterplot of measurement points, for dependence: $q_{\text {wśr }}=f\left(\Delta p_{s r}\right)$ the following three models were selected:
a) Linear model $y=a x+b$,
b) Power model $y=a x^{n}$,
c) Exponential model $y=e^{n x}$. where:

$\mathrm{x}$ - independent variable, $(M P a)$, in linear, power, exponential models,

y - dependent variable, $\left(\frac{m^{3}}{h}\right)$ in linear, power, expo-

a - the slope factor, in linear and power models,

b - the factor determines the point of intersection of the function graph with the $\mathrm{Y}$ axis, in linear model,

$\mathrm{n}$ - function exponent, in power and exponential models.

$\mathrm{R}^{2}$ - coefficient of determination, [-], (Kukuła, 2006; Jóźwiak and Podgórski, 2012). 
Table 2. List of selected statistics parameters for the determined dependency models: $q_{w s r}=f\left(\Delta p_{s r}\right)$

\begin{tabular}{|l|l|l|l|l|l|l|}
\hline No. & $\begin{array}{l}\text { Regression } \\
\text { model }\end{array}$ & $\begin{array}{l}\text { No. of } \\
\text { measurements }\end{array}$ & $\begin{array}{l}\text { Coefficient of } \\
\text { determination } \\
\boldsymbol{R}^{\mathbf{2}}\end{array}$ & $\begin{array}{l}\text { Measurement } \\
\text { range for } \boldsymbol{q}_{\boldsymbol{w s} \mathbf{r}} \\
\left(\frac{\boldsymbol{m}^{3}}{\boldsymbol{h}}\right)\end{array}$ & $\begin{array}{l}\text { Measurement } \\
\text { range for } \Delta \mathbf{p}_{\text {sr }} \\
(\boldsymbol{M P a})\end{array}$ & Regression equation \\
\hline 1 & linear & 17 & 0.4953 & $0.36 \div 21.0$ & $2.47 \div 14.5$ & $y=-0.981 x+13.147$ \\
\hline 2 & power & 17 & 0.6438 & $0.36 \div 21.0$ & $2.47 \div 14.5$ & $y=109.2 x^{-1.813}$ \\
\hline 3 & exponential & 17 & 0.6715 & $0.36 \div 21.0$ & $2.47 \div 14.5$ & $y=21.942 e^{-0.244 x}$ \\
\hline
\end{tabular}

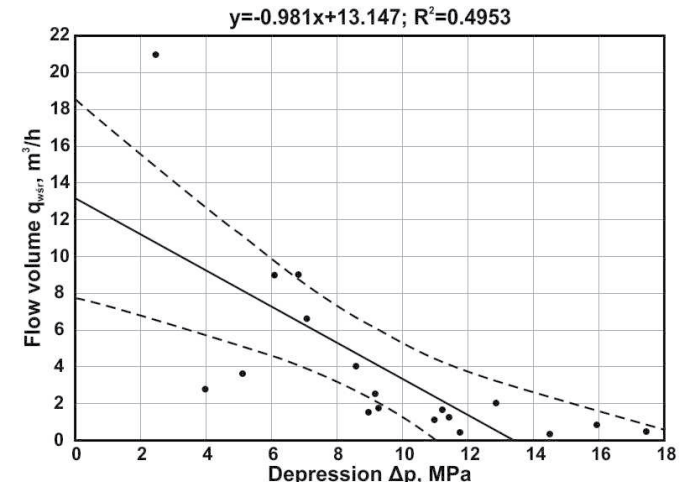

(a)

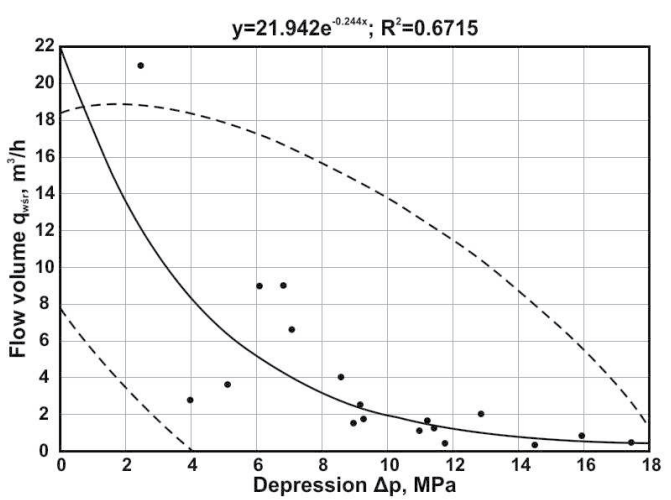

(c)

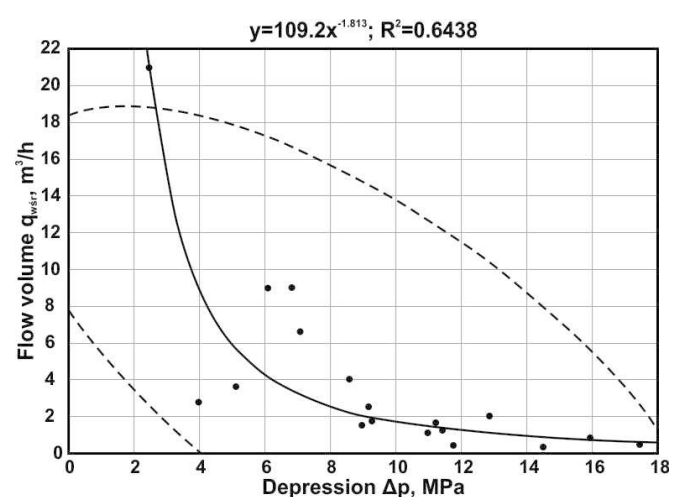

(b)

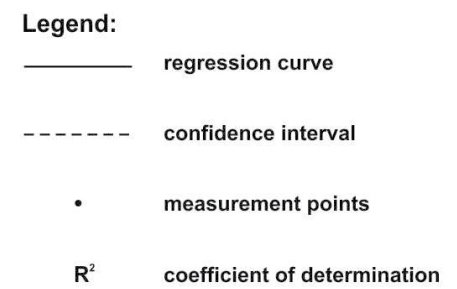

Legend:

$\mathbf{R}^{2} \quad$ coefficient of determination

Figure 3. The approximation of the distribution of the measurement points of the dependence $q_{w s r}=f\left(\Delta p_{s r}\right)(\mathrm{a})$ based on the linear model, (b) based on the power model, (c) based on the exponential model.

The determined regression equations and statistical parameters are presented in Table 2.

As a result of the analysis, it was found that the worst correlation between variables was obtained for the linear model $\left(\mathrm{R}^{2}=0.4953\right)$ (see Figure 3a), then for the power model $\left(\mathrm{R}^{2}=0.6438\right)$ (see Figure $\left.3 \mathbf{b}\right)$, and the best for the exponential model $\left(\mathrm{R}^{2}=0.6715\right)$ (see Figure 3c). From these graphs, a very significant conclusion can be drawn that in the case of DST testing of carbonate, fracturedreservoir rocks, as the depression of pressure increases, the flow rate of the reservoir water flowing into the wellbore decreases. On the basis of this observation, it can be concluded that in the Mesozoic fractured reservoir rocks, in the studied area of the Carpathian Foredeep, in cases of extreme pressure depressions, there are changes in the permeability of reservoir rocks in the perimeter zone. The reason for these changes may be the shortening of fractures and microfractures, as well as the movement of mobile solid particles towards the well (salt, rust, polymers, cuttings, clayey particles and others) sticking fractures, microfractures, as well as channels connecting large cavities. Another reason could also be reservoir deliverability or the aquifer volume. As it was concluded, a bigger $\Delta \mathrm{p}$ means less flow through the sampler (Dubiel et al., 2003; Dubiel and Uliasz-Misiak, 2012).

Not all of the determined regression equations are suitable for predicting the expected value of the water volume stream (y) for the designed mean depression $(\mathrm{x})$, 
Table 3. List of values of water volume flows predicted using regression equations determined for the three considered models

\begin{tabular}{|c|c|c|c|c|c|}
\hline \multirow[b]{2}{*}{ No. } & \multirow[b]{2}{*}{ Regression model } & \multirow{2}{*}{ Regression equation } & $x=5(M P a)$ & $x=7.5(M P a)$ & $x=10(M P a)$ \\
\hline & & & \multicolumn{3}{|l|}{$\left(m^{3}\right)$} \\
\hline 1 & linear & $y=-0.981 x+13.147$ & 8.217 & 5.752 & 3.287 \\
\hline 2 & power & $y=109.2 x^{-1.813}$ & 5.902 & 2.830 & 1.680 \\
\hline 3 & exponential & $y=21.942 \mathrm{e}^{-0.244 x}$ & 6.478 & 3.520 & 1.912 \\
\hline
\end{tabular}

because the coefficients of determination have different values. For example, the predicted values of the reservoir water volume for the given mean pressure depression values $(5,7.5$ and $10 \mathrm{MPa})$, for the three analyzed models, are summarized in Table 3. As can be seen in Table 3, the predicted values of the water flow rate differ too much between each other. On this basis, the linear model was rejected due to the low value of the determination coefficient and large differences in the predicted values of the volume flow of the reservoir water inflow in comparison with the power and exponential models (see Table 3).

Table 3 shows, that in the case of the assumed pressure depression of $5 \mathrm{MPa}$, the linear model inflates the forecast of the water flow volume by about $39 \%$ in relation to the power model and about $27 \%$ in relation to the exponential model. However, in the case of pressure depression of $10 \mathrm{MPa}$, the deviations of the predicted values of the flow rate of water flow are as much as about $96 \%$ and $72 \%$, respectively.

Large errors in forecasting the flow rate of the reservoir water flow to the sampler at a given bottom pressure depression of up to $96 \%$ (see Table 3 ) may result from:

- the considerable heterogeneity of the pore-fracture space of the Mesozoic carbonate strata (Dubiel et al., 2012),

- the different degree of gasification of the reservoir water with natural gas (no taken into account in the industry when determining the value $\left(q_{\text {wss }}\right)$ (Dubiel et al., 1998),

- too few analyzed measurement data, hardly available in industry.

A good measure of the productivity of the tested aquifer is the unit extraction rate $\left(W W_{j}\right)$. It allows for the assessment of reservoir parameters with regard to the technological parameters used.

Using methods of statistical analysis, based on the scatterplot of measurement points, for the dependence: $W W_{j s r}=f\left(\Delta p_{s r}\right)$, were chosen, as before, the following three models: the linear model (see Figure 4a), the power model (see Figure 4b) and the exponential model (see Figure 4c). The determined regression equations and statistical parameters are summarized in Table 4.
Based on the results summarized in Table 4, it can be concluded that the linear regression equation is not suitable for predicting the value $(y)$ at the design value $(x)$, due to its too low coefficient of determination. On the other hand, power and exponential models have much higher determination coefficients than a linear model (see Table 4), so the regression equations determined for these models are suitable for forecasting.

The predicted values of unit extraction rates, for given average values of pressure depression (5, 7.5 and 10 $M P a$ ), for the three analyzed models, are presented in Table 5.

Analyzing the predicted $W W_{j}$ values summarized in Table 5, it can be concluded that the power and exponential regression equations are suitable for predicting the measured value, wherein the difference between the predicted values decreases with the increase in pressure depression, especially in the range 7.5-10 $\mathrm{MPa}$ (see Table 5). This is an important observation due to the widespread use of pressure depression in the industry, in the above-mentioned range. Correlation dependencies and regression equations (see Figures 3-4) were determined using measurement points with confidence intervals with a confidence value of 0.95 .

Based on the histogram of the values of unit production rates of $W W_{j}$ (see Figure 5), the following statistical parameters were determined: the average of the distribution series is $0.8544 \frac{m^{3}}{h \cdot M P a}$; the median is $0.189 \frac{m^{3}}{h \cdot M P a}$; the standard deviation is $1.8122 \frac{\mathrm{m}^{3}}{h \cdot M P a}$. The high standard deviation value is due to the open character of the $W W_{j}$ distribution series. The median value of $0.189 \frac{m^{3}}{h \cdot M P a}$ (as the central value of the measurement data set) is usually a good practical measure of the analyzed value. In the analyzed case, this value indicates a low commercial value of the analyzed waterbearing horizons of the Mesozoic strata in the considered area. However, due to occurrence of the Mesozoic carbonate reservoir rocks, it is possible to apply acidizing to increase the extraction of reservoir water (Falkowicz et al., 2012). 
Table 4. List of selected statistics parameters, for determined dependency models $W W_{j}=f\left(\Delta p_{s r}\right)$

\begin{tabular}{|l|l|l|l|l|l|l|}
\hline No. & $\begin{array}{l}\text { Regression } \\
\text { model }\end{array}$ & $\begin{array}{l}\text { No. of } \\
\text { measurements }\end{array}$ & $\begin{array}{l}\text { Coefficient of } \\
\text { determination } \\
\boldsymbol{R}^{\mathbf{2}}\end{array}$ & $\begin{array}{l}\text { Measurement } \\
\text { range for } \boldsymbol{W W}_{j} \\
\left(\frac{\boldsymbol{m}^{\mathbf{3}}}{\boldsymbol{h} \cdot \boldsymbol{M P a}}\right)\end{array}$ & $\begin{array}{l}\text { Measurement } \\
\text { range for } \Delta \mathbf{p}_{\text {sr }} \\
(\boldsymbol{M P a})\end{array}$ & Regression equation \\
\hline 1 & linear & 17 & 0.3871 & $0.025 \div 7.664$ & $2.47 \div 14.5$ & $y=-0.3076 x+3.681$ \\
\hline 2 & power & 17 & 0.8087 & $0.025 \div 7.664$ & $2.47 \div 14.5$ & $y=100.81 x^{-2.778}$ \\
\hline 3 & exponential & 17 & 0.8148 & $0.025 \div 7.664$ & $2.47 \div 14.5$ & $y=8.1244 e^{-0.368 x}$ \\
\hline
\end{tabular}

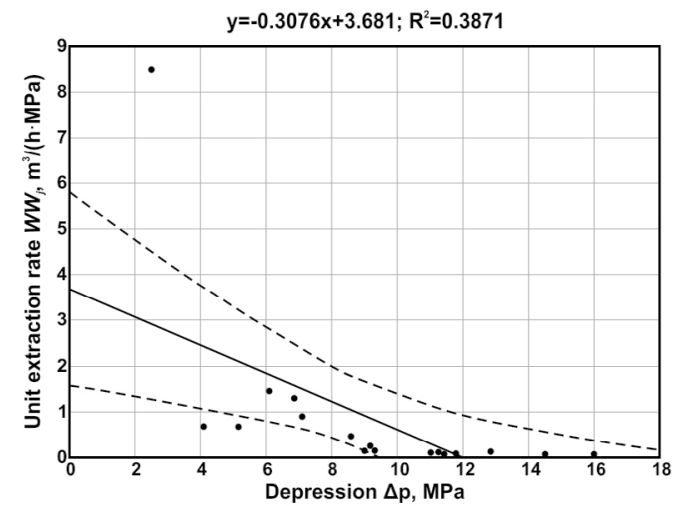

(a)

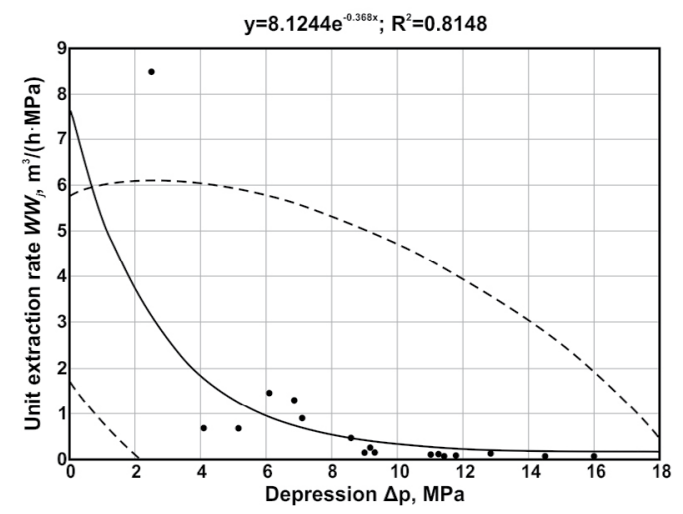

(c)

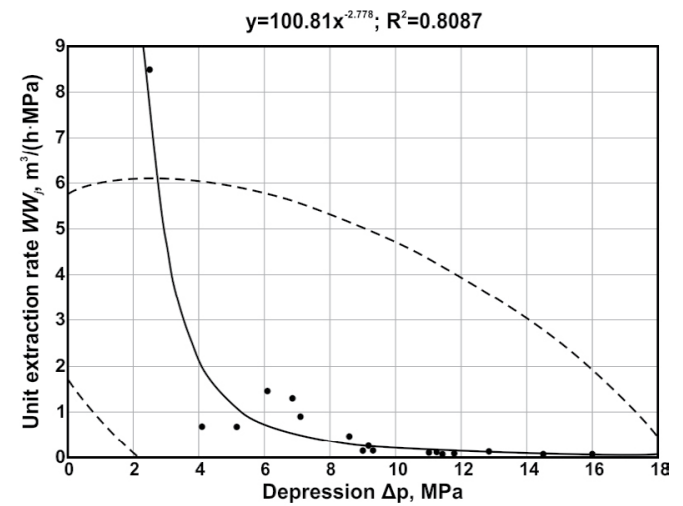

(b)

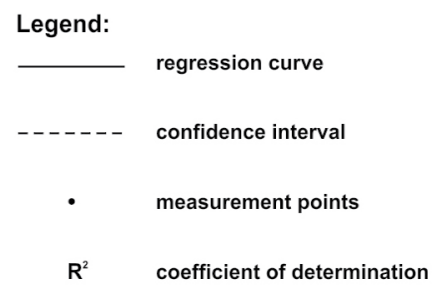

Figure 4. The approximation of the distribution of the measurement points of the dependence $W W_{j}=f\left(\Delta p_{s r}\right)(\mathrm{a})$ based on the linear model, (b) based on the power model, (c) based on the exponential model

Table 5. Comparison of the values of unitary reservoir water production indices predicted using regression equations determined for the three considered models

\begin{tabular}{|c|c|c|c|c|c|}
\hline \multirow{2}{*}{ No. } & \multirow{2}{*}{ Regression model } & \multirow{2}{*}{ Regression equation } & $x=5(M P a)$ & $x=7.5(M P a)$ & $x=10(M P a)$ \\
\hline & & & \multicolumn{3}{|l|}{$y,\left(\frac{m^{3}}{h}\right)$} \\
\hline 1 & linear & $y=-0.3076 x+3.681$ & 2.143 & 1.374 & 0.605 \\
\hline 2 & power & $y=100.81 x^{-2.778}$ & 1.153 & 0.374 & 0.168 \\
\hline 3 & exponential & $y=8.1244 e^{-0.368 x}$ & 1.290 & 0.514 & 0.205 \\
\hline
\end{tabular}




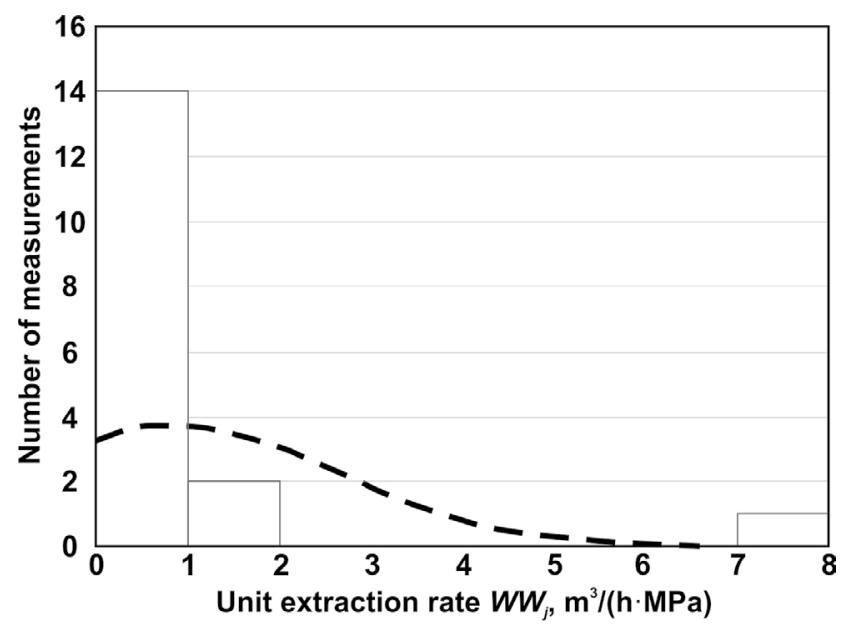

Figure 5. Histogram of the value of unit extraction rate $W W_{j}$

\section{Conclusions}

In the case of the DST testing of carbonate, fractured carbonate reservoir rocks of the Mesozoic in the selected region of the Carpathian Foredeep, as the depression of pressure increases, the value of the stream volume of the reservoir water flowing into the well decreases. This observation should be considered when designing DST test technology parameters.

The aim of the statistical analyses was to obtain the highest possible values of the determination coefficient, which proved the best possible adjustment of the regression curve to the measurement points.

Based on a statistical analysis of industrial data from 17 two-cycle DST tests of water-bearing Mesozoic horizons, it was found, inter alia:

satisfactory correlation of the water flow $q_{\text {ws } r}$ as a function of the average pressure depression $\Delta p_{\dot{s}}$; however, from the three models studied (linear, power and exponential), the best correlation was obtained for the exponential $\left(\mathrm{R}^{2}=0.6715\right)$ and power $\left(\mathrm{R}^{2}=0.6438\right)$ model, while for the linear $\left(\mathrm{R}^{2}=0.4953\right)$ model, a weak correlation was obtained, therefore it was considered unsuitable for forecasting the water outflow at a given depression (see Table 2),

$>$ regression equations determined for exponential and power models are suitable for forecasting the water flow volume for the projected average pressure depression, however with different accuracy; namely: as the depression increases, the difference between the forecasting results decreases.

Differences in the predicted values of streams of reservoir water flow to the sampler at a given bottom pressure depression may result from:

- a small number of analyzed measurement data,

- from high variability of reservoir water flow conditions in a pore-fracture,
- fracture-pore and cavernous Mesozoic carbonate rocks in the studied area of the Carpathian Foredeep, as well as from the different content of natural gas in the reservoir water.

The median value of the $W W_{j}$ parameter $(0.189$ $\left.\frac{m^{3}}{h \cdot M P a}\right)$ indicates a low commercial value of the tested aquifers built of Mesozoic carbonate rocks. However, this assessment should consider the fact that the acidizing of these rocks, with suitably selected technology, can significantly increase the rate of extraction of reservoir water, as a result of re-opening rocks of the perimeter zone.

\section{Acknowledgements}

This study was supported by AGH University of Science and Technology, Faculty of Drilling, Oil and Gas statutory research No. 16.16.190.779. Special thanks to J. Kowal-Kasprzyk, Ph.D., for sharing the geological map, which improved our paper.

\section{References}

Borys, Z., Mysliwiec, M. and Trygar, H. (2000): New gas discoveries in the Carpathian Foredeep, Poland, as the result of the seismic anomalies interpretation. Oil and Gas News from Poland, 10, 69-80.

Cieszkowski, M., Golonka, J., Krobicki, M., Ślączka, A., Oszczypko, N., Waśkowska, A. and Wendorff, M. (2009): The Northern Carpathians plate tectonic evolutionary stages and origin of olistoliths and olistostromes. Geodinamica Acta, 22, 101-126. https://doi.org/10.3166/ga.22.101-126

Cisek, B. and Czernicki, J. (1965): Występowanie siarki w poziomie osadów chemicznych tortonu dolnego na Przedgórzu Karpat w rejonie Rokietnica-Mirocin-JarosławKańczuga jako ważny wskaźnik w poszukiwaniach bituminów. (The occurence of sulfur in the level of chemical sediments of the lower tortonium in the Carpathian Foredeep in the Rokietnica-Mirocin-Jarosław-Kańczuga region as an important indicator in the search for bitumen). Geologia i Geofizyka Naftowa, 10-12, 317-318. (in Polish - without English abstract)

Czernicki, J., and Moryc, W. (1990): Oil field Nosówka by Rzeszów. Nafta, 4-6, 49-54. (in Polish - without English abstract)

Dubiel, S., Chrząszcz, W. and Rzyczniak, M. (2003): Problemy opróbowania warstw perspektywicznych rurowymi próbnikami złoża. (Problems of perspective zones testing with drill stem testers). Uczelniane Wydawnictwa Naukowo-Dydaktyczne AGH, Kraków, 223 pp. (in Polish without English abstract)

Dubiel, S., Rzyczniak, M., Wójtowicz, T. and Kułaga, T. (1998): Analiza i interpretacja wyników badań rurowymi próbnikami złoża warstw perspektywicznych w rejonie Przedgórza Karpat, w celu oceny właściwości zbiornikowych skał i parametrów złożowych poszczególnych poziomów. (Analysis and interpretation of the results of studies 
with drill stem testers of perspective layers in the area of the Carpathian Foredeep in order to assess the reservoir properties of rocks and reservoir parameters of individual horizons). AGH Kraków, 153 pp. (in Polish - without English abstract)

Dubiel, S. and Uliasz-Misiak, B. (2012): Wpływ ciśnienia różnicowego na wydatek wody złożowej podczas badań rurowymi próbnikami złoża utworów miocenu autochtonicznego w zapadlisku przedkarpackim (Influence of differential pressure on formation water flow rate during tests of the autochtonous Miocene deposits in the Carpathian foredeep with DST), Gospodarka Surowcami Mineralnymi, 28, 1, 157-171. (in Polish - with English abstract)

Dubiel, S., Zubrzycki, A., Rybicki, C. and Maruta, M. (2012): Application of DST interpretation results by $\log -\log$ method in the pore space type estimation for the Upper Jurassic carbonate reservoir rocks of the Carpathian Foredeep basement. Archives of Mining Sciences, 57, 2, 413-424.

Falkowicz, S., Dubiel, S. and Cicha-Szot, R. (2012): Problemy ograniczania dopływu wody do odwiertów wydobywczych gazowych i ropnych (Case studies of water shut-off treatments in oil and gas production wells). Gospodarka Surowcami Mineralnymi, 28, 1, 125-136. (in Polish - with English abstract)

Głuszyński, A. and Aleksandrowski, P. (2016): A deep palaeovalley in the floor of Polish Carpathian Foredeep Basin near Pilzno and its control on Badenian (middle Miocene) evaporite facies. Geological Quarterly, 60, 493-516.

Gutowski, J., Urbaniec, A., Złonkiewicz, Z., Boberek, L., Świetlik, B. and Gliniak, P. (2007): Stratygrafia górnej jury i dolnej kredy środkowej części przedpola polskich Karpat. (Upper Jurassic and Lower Cretaceous of the middle Polish Carpathian Foreland). Biuletyn PIG, 426, 1-26. (in Polish - with English abstract and summary)

Heflik, W. (1992): Petrografia utworów roponośnych z wiercenia Nosówka 2 koło Rzeszowa (Petrography of oil reservoir from the Nosówka 2 well near Rzeszów). Nafta-Gaz, 7-8, 161-165. (in Polish - with English abstract)

Jóźwiak, J. and Podgórski, J. (2012), Statystyka od podstaw (Basics of statistics), Polskie Wydawnictwo Ekonomiczne, Warszawa, 510 pp. (in Polish)

Karnkowski, P. (1994): Miocene deposits of the Carpathian Foredeep (according to results of oil and gas prospecting). Geological Quarterly, 38, 3, 377-394.

Karnkowski, P. (1999): Oil and gas deposits in Poland. The Geosynoptics Society GEOS - University of Mining and Metallurgy, Cracow, 380 pp.

Karnkowski, P.H. and Ozimkowski, W. (1998): The distribution of oil- and gasfields in relation to satellite image interpretation: An example from the Polish East Carpathians and the adjacent foredeep. Journal of Petroleum Geology, 21, 2, 213-231.

Kotarba, M., Burzewski, W., Wilczek, T., Slupczynski, K., Kosakowski, P. and Botor, D. (1998): Model of gaseous hydrocarbon generation in the Miocene strata of the Polish part of the Carpathian Foredeep. Przegląd Geologiczny, 46, 737-742. (in Polish - with English abstract)
Kovac, M., Nagymarosy, A., Oszczypko, N., Slaczka, A., Csontos, L., Marunteanu, M., Matenco, L. and Marton, E. (1998): Palinspastic reconstruction of the CarpathianPannonian region during the Miocene. In: Rakus, M. (ed.), Geodynamic development of the Western Carpathians: Bratislava. Slovak Geological Survey, 189-217.

Kowal-Kasprzyk, J., Krajewski, M. and Gedl, P. (2020): The oldest stage of the Outer Carpathian evolution in the light of Oxfordian-Kimmeridgian exotic clast studies (southern Poland). Facies 66, 11. https://doi.org/10.1007/s10347020-0595-y.

Krajewski, M., Matyszkiewicz, J., Król, K., Olszewska B. (2011): Facies of the Upper Jurassic - Lower Cretaceous deposits from the southern part of the Carpathian Foredeep basement in the Kraków - Rzeszów area (southern Poland). Annales Societatis Geologorum Poloniae, 81, 3, 269-290.

Krzywiec, P. (2006): Geodynamiczne i tektoniczne uwarunkowania ewolucji basenów przedgórskich, z odniesieniami do zapadliska przedkarpackiego (Geodynamic and tectonic control on evolution of foreland basins, with references to the Carpathian Foredeep Basin). Przegląd Geologiczny 54, 404-412. (in Polish - with English summary)

Kukuła, K. (2006): Elementy statystyki w zadaniach. (Statistics elements in tasks.). Wydawnictwo Naukowe PWN, Warszawa, 260 pp. (in Polish)

Maksym, A., Baszkiewicz, A., Gregosiewicz, Z., Liszka, B. and Zdanowski, P. (2000): Facies and reservoir potential of the uppermost Jurassic and the Lower Cretaceous deposits in Brzezowka-Zagorzyce region versus geologic structure of the southern Carpathian Foredeep. Przegląd Geologiczny, 49, 401-407.

Mizerski, W. (2020): Geologia Polski (Geology of Poland). Wydawnictwo Naukowe PWN. Warszawa, 311 pp. (in Polish)

Myśliwiec, M. (2004): Typy pułapek gazu ziemnego i strefowość występowania ich złóż w osadach miocenu wschodniej części zapadliska przedkarpackiego (Traps for gas accumulations and the resulting zonation of the gas fields in the Miocene strata of the eastern part of the Carpathian Foredeep (SE Poland)). Przegląd Geologiczny 52, 657- 664. (in Polish - with English summary)

Myśliwiec, M., Borys, Z., Bosak, B., Liszka, B., Madej, K., Maksym, A., Oleszkiewicz, K., Pietrusiak, M., Plezia, B., Staryszak, G., Świętnicka, G., Zielińska, Cz., Zychowicz, K., Gliniak, P., Florek, R., Zacharski, J., Urbaniec, A., Górka, A., Karnkowski, P. and Karnkowski, P.H. (2006): Hydrocarbon Resources of the Polish Carpathian Foredeep: Reservoirs, Traps and Selected Hydrocarbon Fields. In: Golonka, J. and Picha, F.J. (eds.): The Carpathians and their Foreland: Geology and Hydrocarbon resources. AAPG Memoir, 84, 351-393.

Oszczypko, N. (1998): The Western Carpathian Foredeep Development of the foreland basin in front of the accretionary wedge and its burial history (Poland). Geologica Carpathica, 49, 1-18.

Oszczypko, N. (2006): Powstanie i rozwój polskiej części zapadliska przedkarpackiego (Development of the Polish sector of the Carpathian Foredeep). Przegląd Geologiczny 54, 396-403. (in Polish - with English abstract) 
Oszczypko, N., Krzywiec, P., Popadyuk, I. and Peryt, T. (2006): Carpathian Foredeep Basin (Poland and Ukraine): Its Sedimentary, Structural, and Geodynamic Evolution. In: Golonka, J. and Picha, F.J. (eds.): The Carpathians and their foreland: Geology and hydrocarbon resources. AAPG Memoir, 84, 293-350.

Oszczypko, N. and Slaczka, A. (1989): The evolution of the Miocene basin in the Polish Outer Carpathians and their foreland. Geologica Carpathica, 40, 23-36.

Stupnicka, E. and Stempień-Sałek, M. (2016): Geologia regionalna Polski (Regional geology of Poland). Wydawnictwo Uniwersytetu Warszawskiego. Warszawa, 339 pp. (in Polish)

Szuflicki, M., Malon, A. and Tymiński, M. (eds) (2020): Bilans zasobów złóż kopalin w Polsce wg stanu na 31 XII
2019 r. (The balance of mineral resource deposits in Poland as of 31 XII 2019). Państwowy Instytut Geologiczny - Państwowy Instytut Badawczy, Warszawa, 497 pp. (in Polish)

Tomek, C. and Hall, J. (1993): Subducted continental margin imaged in the Carpathians of Czechoslovakia. Geology, 21, 535-538.

Żytko, K., Zając, R., Gucik, S., Ryłko, W., Oszczypko, N., Garlicka, I., Nemcok, J., Elias, M., Mencik, E. and Stranik, Z. (1989): Map of the tectonic elements of the Western Outer Carpathians and their foreland 1:500 000. In: Poprawa, D. and Nemcok, J. (eds.): Geological Atlas of the Western Outer Carpathians and Their Foreland. Polish Geological Institute, Warszawa.

\section{SAŽETAK}

\section{Utjecaj depresije na pritok vode $u$ bušotine $u$ karbonatnim podinama Karpatskoga predgorja na jugoistoku Poljske}

U radu je prikazana analiza rezultata testiranja bušotina metodom DST-a (engl. skr. od Drill Stem Testing). Istraživanjem su obuhvaćene razine karbonata u stijenama mezozojskih ležišta u Karpatskome predgorju. Na temelju sedamnaest testova ispitivanja ležišta metodom DST-a, provođenih u dvama ciklusima, istražena je ovisnost volumena protoka vode iz mezozojskih karbonatnih ležišta (gornja jura i donja kreda) u bušotine, a kao funkcija prosječne depresije zbog tlaka na dnu bušotine. Kao objekti istraživanja odabrani su oni smješteni upravo u naftnoj zoni Karpatskoga predgorja, na jugoistoku Poljske. Na temelju statističke analize uočena je zadovoljavajuća korelacija između varijabli potencijskoga i eksponencijalnoga modela te slaba korelacija kod linearnoga modela. Smanjenje pritoka ležišne vode iz mezozojskih karbonatnih ležišta, uz povećanje depresije, potencijalno upućuje na pojavu smanjivanja pukotina i mikropukotina uslijed prevelike depresije te na začepljivanje fraktura i šupljina nastalih otapanjem, do čega dolazi zbog krutih čestica poput krhotina, soli, polimera itd.

\section{Ključne riječi:}

Karpatsko predgorje; mezozoik; iskušavanje stijena metodom DST-a; statistika; volumni protok vode

\section{Author's contribution}

Mirosław Rzyczniak (Ph.D. in Petroleum Engineering) and Dagmara Zeljaś (Ph.D. in Environmental Engineering) performed statistical analysis along with the interpretation and discussion. Marek L. Solecki (M. Sc. in Petroleum Geology and Ph.D. Candidate) described the geological setting of the research area. Stanisław J. Dubiel (Professor Emeritus in Petroleum Engineering) participated in writing the introduction, conclusions and the interpretation of the results. 